\title{
Measuring And Communicating The Value Created By An Organization
}

W. Richard Sherman, Saint Joseph's University, USA

\begin{abstract}
This paper offers a different perspective in measuring the value created by an organization. It does so in the context of an undergraduate course in managerial accounting. In order to breakdown the functional silo approach to problem solving that has become the model of traditional business education, applications of shadow accounting, the balanced scorecard (BSC), Triple Bottom-Line (TBL), and other measures are introduced to challenge students to broaden their ideas of the function of the firm and the value that firm creates.
\end{abstract}

Keywords: Value creation; management accounting; balanced scorecard; sustainability accounting

\section{INTRODUCTION: WHAT WOULD YOU LIKE TO KNOW ABOUT A COMPANY?}

\begin{abstract}
begin every semester by asking my students this question. What would you like to know about a company? As expected, the responses I get often do depend on the level of the course I am teaching freshman, upper level undergraduate, graduate, executive - but they have a common theme. Even though they may not articulate it as such, students want to know what value the company has created in the past, is creating currently, and will create in the future. What is most interesting to me is they never limit their answers to knowing about the creation of financial value. Some want to know whether a company is a good corporate citizen. Others ask if it is environmentally responsible. Still others are concerned with whether the firm is responsive to the needs of its employees, consumers, and community. Without even knowing it, they adopt a stakeholder approach to value creation and want to have some broader measures of organizational success than profit \& loss, liquidity, solvency, budget variances, and other conventional accounting metrics.
\end{abstract}

This paper presents some examples of how accounting can be used to measure the various types of value created by an organization. It does so in the context of an undergraduate managerial accounting course but the ideas presented are easily adaptable to other more advanced courses.

\section{A GENERAL FRAMEWORK OF TEACHING VALUE CREATION}

Rather than blindly accepting that the function of a business is to maximize shareholder wealth, the stakeholder model emphasizes that the purpose of a company is not to maximize profits, shareholder wealth or anything else for that matter, but to create value for a group of key stakeholders and to perpetuate the value-creating capability of the organization over the long-term. By using a series of examples, assignments, team projects, and class discussions, students are challenged to develop an understanding of what the concept of value is for each stakeholder group, how value is or fails to be measured appropriately, and how the types of value created are interrelated. It quickly becomes apparent to students that each of these stakeholders - customers, employees, owners, and others such as the local community, places a legitimate claim on the company. Sometimes these claims are mutually supportive; at other times they clash. The challenge of a business then is to manage these legitimate but sometimes conflicting claims on the company so as to sustain the long-term health of the organization.

\section{VALUE CREATION FOR THE CUSTOMER: THE MIRACLE BLADE®}

After asking students what they would like to know about a company, I follow-up with a demonstration of the amazing Miracle Blade ${ }^{\circledR}$. What is so miraculous about the Miracle Blade ${ }^{\circledR}$ ? For starters, the Miracle Blade ${ }^{\circledR}$ 
has the strength to cut through an aluminum can but has the sharpness and precision to slice a tomato without squirting juice all over the user. How do I know this? First of all, there is the Chef Tony promotional video from the website (http://www.miracleblade.com/). However, to answer the skeptics among my students who are savvy to tricks of videography, I perform this amazing feat right in front of them. Be careful though; these knives are really sharp - as attested to by Jennifer of New Jersey:

Ok so here it is I love these knives! I got them actually for my mommy for Christmas two years ago and we use them every day they are really good and sharp... so sharp that they do borderline ummm too sharp. I was washing dishes and I washed some older knives and even some new ones as $i$ would normally .. then i get to the the Miracle Blade steak knives and went to wash them .... well $i$ ended up in the emergancy room with stiches ..... just be careful they are really quite sharp.

(http://www.infomercialratings.com/product/miracle blade)

If Jennifer's review isn't enough (in addition to the misspellings, she does seem to be kind of young and naïve, doesn't she?), there's Professor X, who posted this comment:

We have a joke around the house, "They call them the miracle blades because it's a miracle if you don't cut your fingers off!" That's how sharp they are. I think the infomercial is 100\% accurate with regard to the sharpness of these knives. And unlike some other reviewer(s) I have never noticed any deterioration in the level of razor sharpness. . . Overall, I feel the knives are an OK value, just WATCH YOUR FINGERS!! One false move and you may have to go to the emergency room! (And I'm not kidding about that! Can you tell I've had a couple close calls?!?)

(http://www.epinions.com/review/Miracle_Blade_Perfection_Series_Knives/content_155639582340)

However, I think the truly amazing thing about the Miracle Blade ${ }^{\circledR}$ is that it comes with a "lifetime guarantee." So what is a lifetime guarantee? How long does a lifetime guarantee last? Whose lifetime are we measuring? The purchaser's? The user's? The knife's itself (which would seem nonsensical)? Suppose a 58-year old professor buys the Miracle Blade ${ }^{\circledR}$ and gifts it to one of his 18-year old students. Is the Miracle Blade ${ }^{\circledR}$ guaranteed for the life of the professor or of the student - or for the life of someone else? I am really not sure but despite the entertaining exchanges I have with my students on this very first day of class, there is a completely different point I try to make. Regardless of the length of a lifetime guarantee, it can only last as long as the company that makes the Miracle Blade ${ }^{\circledR}$ is still in business. And how can we know how long that will be? That's where accounting comes in. Certainly, accounting cannot give a definitive answer but by collecting, measuring, and communicating information about the financial performance and health of a company, accounting can provide decision-makers (like the purchasers, users, and owners of the Miracle Blade $\left.{ }^{\circledR}\right)$ with some insights about the value created for the consumer by the company's products and the lifetime guarantee to assure quality. Of course, this also assumes that the company will be responsive to its warranty. Some consumers have not been totally satisfied with the Miracle Blade ${ }^{\circ}$ in this regard. Ron of Michigan writes:

Bought 2 sets of these knife a while ago. The scissors broke but the knifes really aren't that bad for the price. One of the chop and scoops broke in half in the middle of the blade. Sent it in for the warranty around 2 years ago and have yet to receive the new knife. So I would say the warranty is bull

(http://www.infomercialratings.com/product/miracle blade).

For many, the Miracle Blade exercise gives students their first exposure to how accounting does help evaluate value creation, in this case, the value created for a consumer. Throughout the semester, we continue to explore what value is being created by an organization and how accounting helps measure and communicate that creation.

\section{ENVIRONMENTAL VALUE CREATION: RED GOES GREEN}

On April 30, 2008, the Philadelphia Phillies, at the time the reigning champions of Major League Baseball's National League Eastern Division, later the 2008 World Series Champions, announced that to offset the power usage at the team's home stadium, Citizens Bank Park, it had purchased 20 million kilowatt-hours of 
renewable energy certificates, equivalent to planting 100,000 trees. This initiative was the largest single purchase of $100 \%$ renewable energy in professional sports to date

(http://mlb.mlb.com/news/press_releases/press_release.jsp?ymd=20080430\&content_id=2614303\&vkey=pr_phi\&fe $\underline{\left.x t=. j s p \& c \_i d=p h i\right)}$.

How did the Phillies come up with that calculation? How does it know that the 20 million kilowatt-hours will make the organization "energy-neutral"? Do you think accountants had something to do with it? Of course they did and the role of the accountant in measuring and communicating information about the carbon footprint of an organization will only increase.

The future of the planet may be in the hands of accountants, according to a new survey by JustAccountancyJobs.com. Three-quarters (75\%) of the 180 finance professionals surveyed by the website agreed that carbon offsetting - whether voluntary or compulsory - would become a reality at their firms within just five years, compared with only $18 \%$ doing so now.

An even greater proportion, $85 \%$, believe an accountant will eventually be involved in calculating carbon offsetting at their firm. This compares with just $11 \%$ who say an accountant is currently involved.

"Carbon offsetting is accountancy's next big challenge and developing the skill set needed to navigate this exciting new field could be make-or-break in an accountant's career," said Sacha Deakin, account manager at JustAccountancyJobs.com.

"Not only are accountants becoming more aware of the need to protect the planet - they are starting to realise that they will have a crucial role to play."

(JustAccountancyJobs.com, 2008)

The creation of value is not limited to profits and balance sheet assets or net worth. An organization creates (or destroys) more than economic or financial value. It impacts the environment, the community, its employees and customers, and society as a whole. Consequently, the role of accounting in measuring and communicating value creation should not be limited to financial statements or internal reports for budgeting and control purposes.

Rob Gray argues that accounting "makes visible that which is currently invisible in organizational settings" (Gray, 1992). He makes an even stronger argument about accounting's role in environmental reporting:

(A)ccounting is the score-keeper. The 'score' takes no account of environmental matters and so, as a result, neither does 'economic' decision-making. Given the importance of accounting information and the way in which we account it seems inevitable therefore that 'economic' decisions must be environmentally malign. The environmental crisis is an inevitable result of the way we accountants do what we do. Accounting bears a serious responsibility for the growing level of environmental devastation (Gray et al., 1993: 22).

Perhaps Gray places too much responsibility on accounting and accountants for environmental degradation but his point is well taken. When students recognize what kinds of value are accounted for and, even more significantly, what kinds of value are not, they gain a deeper appreciation of the role and possible shortcomings of accounting.

As a follow-up to "Red Goes Green" example, I ask my students to calculate their carbon footprint using the Terrapass website (http://www.terrapass.com/). While the methodology Terrapass uses to calculate monetary values for the environmental impact is not explained either on the website or in class, the quantification of this external cost to the planet strikes an immediate chord with students. They begin to understand the power which accounting as the score-keeper has. By attaching dollars \& cents to the value created or destroyed by their driving habits, students recognize that the accounting implicit the calculation of the carbon footprint does indeed make visible what was previously invisible. 


\section{COMMUNITY VALUE CREATION: USE OF SHADOW ACCOUNTING}

Extending the discussion of the calculation of a carbon footprint to other ways in which accounting can make a difference in how value creation is perceived, I ask students to create "shadow" accounts which would attach monetary values to various activities in which the corporation engages. A shadow account is not part of the formal accounting system of an organization. Instead, it tracks the impact, usually entirely external, of a company's operations. The published financial statements issued by a company do not reflect these numbers but Rob Gray believes:

To be effective, this shadow accounting system would preferably produce numbers which can be deducted from calculated accounting profit ... . This will, thus, lead to a recognition that organization income has been grossly overstated for some considerable time and that current generations have been benefiting at the cost of some future generations. The probability is that no western company has made a sustainable profit for a very long time, if ever (Gray, 1992, pp. 419-420; italics in the original).

A simple fact pattern will illustrate how this new approach could be used. As is appropriate under GAAP, assets totaling $\$ 1,000$ represent the resources owned by the company at year-end total. The equity side shows the sources of these assets - with $\$ 400$ (or $40 \%$ ) coming from creditors (that is, liabilities) and the remaining $\$ 600$ (or $60 \%$ ) coming from the investment by the owners (the company's stockholders). During 2009, the company reports revenues of $\$ 900$ and expenses of $\$ 500$. These expenses include some external costs (in this case, only $\$ 25$ ) but certainly not all the costs of doing business. Under conventional accounting, $\$ 450$ of the external costs such as costs associated with community involvement - providing employment (or lost employment in cases of downsizing and layoffs), partnering (or the failure to partner) with various community groups to enhance the resources available to residents whether employed by the company or not, etc., have not been "internalized" by the company and would not be reported - not on the company's income statement; not on the company's balance sheet; not anywhere. As a consequence, the Net Income of $\$ 400$ reported on the conventional income statement is overstated inasmuch as it does not account for all of the company's community costs of doing business. Assuming that none of this income is distributed to the owners in the form of dividends, it will increase the owners' stake in the company as shown on the balance sheet's stockholders' equity section.

On the other hand, sustainable stakeholder accounting does account for these external costs by recognizing a "Community Interest" liability and an offsetting Community Investment equity component. This can be viewed as a negative component of the company's equity (a contra-equity account). In essence, the equity which the stockholders have in the company is reduced or compromised by the "equity" sacrificed by other stakeholders who are worse off as a result of the company's operations - in this example, the community in which the business operates. To simplify this example, assume that the entire $\$ 450$ of additional community costs relates to the current period (2009) and as such will be shown as a negative impact on the company's adjusted Profit \& Loss Statement. This adjustment to the company's reported income follows Gray's model of a "parallel" or "shadow" accounting system. Instead of merely reporting a "non-sustainable" profit of $\$ 400$, the adjusted Profit \& Loss Statement reflects more accurately that the company has only been able to generate a sustainable loss of $\$ 50$ after the impact on the community in which it operates (and which is necessary for its successful operation) is taken into account.

As these results from operations flow through to an adjusted Statement of Adjusted Financial Position, the subtotal for "Income Before Community Impact" does indeed increase the Stockholders' Equity section of the balance sheet by $\$ 400$ (to a total of $\$ 1,000$ on 12/31/09). However, the charge for the company's failure to invest in the community also flows to the Statement of Adjusted Financial Position in the form of a liability and as a negative component of the company's equity shown as "Community Equity." Thus, the company's total equities (liabilities plus stakeholder equities) are the same as that reported on a conventional balance sheet - only the composition has changed to highlight the interests of stakeholders (the community, employees, future generations, nature, and so on) other than the stockholders/owners. Moreover, this new form of accounting recognizes and reports the existence of the liability that will have to be satisfied at some point in the future for the company to survive.

A further implication of this new system of reporting can be seen by looking at its affect on two commonly used financial ratios. The Debt to Total Assets (or the similar Debt to Equity ratio) measures the relative 
contribution of creditors to the company's resources. For example, assuming a starting point (before 2009 earnings are calculated) where Liabilities totaled $\$ 400$ and Invested Capital is $\$ 600$, the Debt to Total Asset ratio of .40 indicates that the company has raised $40 \%$ of its capital by way of debt, with the company's owners/stockholders providing the other $60 \%$. From the point of view of creditors (existing or potential), a relatively low Debt to Total Asset ratio is desirable. Indeed, debt covenants frequently set ceilings on how high a company's debt ratio can climb before the loan is technically in default and will be called in. Note that under conventional accounting, this company's Debt to Total Asset ratio is improving (at least, from the perspective of the company's creditors) - falling from .40 to .286 at the end of 2009 . However, by recognizing the negative community impact (Community Liability and negative Community Equity), the company's ratio has actually climbed from .40 to .607 at the end of 2009 . Given this new form of accounting, one which more accurately reflects the true liabilities of the company, creditors would be much less willing to make a loan - or continue to carry an already outstanding loan. In short, in terms of its true financial position, this company is far riskier than conventional accounting would have us believe.

Net Profit Margin measures how much of each dollar of revenue a company is able to bring down to its "bottom line". Under conventional reporting, this company appears to be very profitable with a net profit margin of $44.44 \%$ (that is, 44 cents of each dollar of revenue showing as profit). However, this profit margin is reduced dramatically to a negative $5.56 \%$ by the recognition of the company's negative community impact - proving out Gray's contention that with the use of a "shadow" environmentally-adjusted accounting system, "the resultant data should be both disruptive and shocking" (Gray 1992, p. 417).

The workings of "sustainability adjustments" do not have to be negative. In fact, many company's performance will be enhanced in the eyes of particular shareholders by better communicating the efforts being made to create value for the community, workforce, and/or environment. Continuing on with the above example, assume that during Year 2010 the company engages in positive contributions to the community. Assume further that these contributions total $\$ 200$, with all other revenues and expenses remaining the same as in Year 2009. These "contributions" partially satisfy the previously recognized "community" liability.

While the company's conventional income statement and balance sheet are similar to those for Year 2009, the company's adjusted profit and financial position are dramatically improved by factoring in the information from the community investment made in 2010. This improvement is captured in the company's ratios. Net Profit Margin jumps from a negative $5.56 \%$ in 2009 to $66.67 \%$ in 2010. The company's Debt to Total Assets ratios falls from .607 in 2009 to .36 in 2010, making this a much more attractive (that is, less risky) venture for existing or future creditors.

Clearly, this example is overly simplified for purposes of illustrating the workings of the analytical adjustments that are possible with a shadow account approach. In any year, a company is likely to have both positive and negative impacts. Consequently, it would not be unusual for a stakeholder/use to make both positive and negative adjustments to arrive at a more relevant profit (or loss) with a concomitant increase and decrease in assets, liabilities, and equity. Furthermore, this example has not worked through the impact which these various activities on corporate cash flows.

The primary advantage of implementing a system of shadow account reporting is that by being expressed in monetary units, the impact of the various aspects of a company's performance can be integrated directly into the financial statements and from there, developed into an index or ratio to facilitate analysis. Just as liquidity, solvency, and profitability ratios facilitate the analysis of these aspects of an organization, these analytically adjusted ratios can facilitate the evaluation of the company's socially responsible activities. Moreover, by embedding the financial impact of corporate performance, both positive (community investment, environmental stewardship, social justice initiatives, philanthropy) and negative (such as plant shut-downs, environmental degradation, abuse of workers' rights), in the financial statements, a more comprehensive evaluation of true liquidity, solvency, and profitability can be made. 


\section{TRIPLE BOTTOM LINE VALUE CREATION: NIKE VS. ADIDAS}

Accounting is often referred to as the language of business because of its ability to communicate various dimensions of the performance of an organization. However, annual reports and other regulatory files (e.g. 10Ks) of publicly traded companies fail miserably in telling anything about a company's environmental and social performance. If accounting is supposed to be measuring and communicating value creation, does that mean that a company's environmental and social performance does not create value?

Companies struggle to tell their stories, to communicate the good, and sometimes the bad, that they do in the marketplace, in the community, to and for the environment, and in society. Quite clearly, the challenge of telling the company's story is not being met by current corporate reporting practices. Triple bottom-line (TBL) reporting, a phrase coined by John Elkington in his 1997 book Cannibals with Forks: the Triple Bottom Line of 21st Century Business, aims to remedy this shortcoming by explicitly considering not only the economic or financial performance of a firm but also the company's environmental and social performance. Initial efforts at TBL reporting were plagued by their lack of uniformity, consistency, and comparability in the information being presented. The Global Reporting Initiative (GRI, 2000; 2002; 2006) has attempted to fill this void by developing a detailed framework that is intended to create an analog to the generally accepted accounting principles (GAAP) approach to financial reporting.

Because my students have at this point in their accounting course(s) become familiar with GAAP reporting, it is quite easy to extend this understanding to the GRI framework. Using the published Sustainability Reports (also sometimes titled as Corporate Responsibility, Sustainable Development, Corporate Social, or Corporate Citizenship Reports) of well-known companies, I have my students explore whether the GRI framework really does help measure and communicate the economic, environmental, and social value created by these firms. Students work in teams and select at least two companies operating in the same industry. To illustrate how this project can enhance and broaden the idea of value creation, I use two leaders in the global sporting goods industry - Nike and adidas.

The companies were selected quite intentionally. First of all, these are highly visible companies with which almost every student is familiar. More significantly, they have reputations for being good corporate citizens and have received awards and other recognition for their non-financial performance - and for the reporting of that performance. Furthermore, both prepare their most recent sustainability reports using the GRI's latest G3 Guidelines (GRI, 2006). Given these common characteristics, one would expect a greater ease of comparability between the companies which is one of the paramount goals of the G3 Guidelines.

Some important differences in the company's TBL disclosures may also be expected due to the company's geographic base. There is a general perception that European-based companies are more sensitive to issues of sustainability than are U.S.-based organizations (Kolk, 2008). Consequently, it would be interesting to see if this perception is confirmed by the reporting of a European company (adidas) as compared and contrasted to that of American firm (Nike).

The question at hand is whether the G3 Guidelines facilitate the telling of Nike's and adidas' story. Remembering that the ultimate goal of the GRI framework is to create a generally accepted way of reporting TBL performance, at the end of the analysis, one would expect to be able to conclude that Nike is doing better in terms of its environmental performance or that adidas has superior social performance or to make some other comparison and evaluation of relative performance of the two companies in some non-financial dimension of their operations. In other words, it would seem that we should be able to make judgments about the environmental and social value the companies are creating by using the TBL information reported just as we are able to make judgments about the financial value these companies create using the financial information they report.

At the heart of the GRI's G3 Guidelines are 79 "performance indicators." One of the most striking features of these indicators is how comprehensive they are. They include both direct and indirect economic, environmental, and social impacts (i.e., internal and external impacts). Some are quantitative (e.g. LA1: Total workforce by employment type, employment contract, and region) while others are qualitative (e.g. EC7: Procedures for local hiring and proportion of senior management hired from the local community) in nature. Furthermore, the 
quantitative indicators are expressed in various monetary and non-monetary units of measure. Because of these characteristics, the indicators cannot be added together or subtracted from one another to actually create a "bottom line" for economic or environmental or social performance. This is one of the principal differences between TBL and the shadow accounting approach. Shadow accounting does enable the user to arrive at an analytically adjusted bottom line.

To complicate this analysis further, no standard report structure has emerged. One consequence of this is that the reader of sustainability reports must sift through interviews, case studies, and other narrative techniques in order to try to find information that may not be reported at all. Fortunately, some of these difficulties are mitigated by the GRI requirement that all G3 reports contain a GRI Content Index (Element 3.12) to serve as a kind of roadmap, alerting readers to where in the report the standard disclosures can be found (GRI, 2006, p. 22). However, many of the performance indicators may not be reported at all due to a lack of materiality to the company's operations, a professional judgment on the part of the preparer which is nonetheless a bit subjective. Hopefully, by analyzing the reports of companies operating in the same industry, facing similar challenges in their corporate responsibility, the comparability of information will be enhanced owing to the fact that what is material to one company should be material to another.

From a corporate responsibility perspective, perhaps the greatest challenge for Nike, adidas, and the global sporting goods and apparel industry is the management of their supply chains. The companies do not manufacturer the shoes, apparel, and equipment they sell under their brand-name. Instead the manufacturing of their products is subcontracted to factories, most of which are located in developing nations. Nike, for example, has only around 24,000 employees, the vast majority working in the United States. All other workers are employed by independent suppliers. Nike estimates that of the 800,000 workers in its contract supply chain, $80 \%$ are women between the ages of 18 and 24 (Nike, 2007a, p. 16). Adidas has a very similar, if somewhat more geographically dispersed organizational structure - over 31,000 employees in 150 locations (adidas, 2008b, p. 56). The actual manufacturing of the adidas products is subcontracted to factories located in the same developing countries in which Nike's products are made.

An analysis of the content of the two reports reveals disturbing inconsistencies in the way in which economic, social, and environmental performance is disclosed. Given their common critical issue, of particular interest are the differences in how each company communicates its efforts to manage its supply chain. As part of its response to its critics about workplace abuses, Nike was the first company in the industry to disclose the names and locations of more than 700 of its contract factories (Nike, 2007b). Adidas has refused to do so, citing the competitive disadvantages in doing so. Even without the disclosure of specific factory locations, the "footprint" of the companies suppliers is reported and these footprints are remarkably similar (adidas, 2008a, p. 62-63; Nike, 2007a, p. 25). Despite the similarity in their supply chains, the metrics used to measure performance are non-comparable. For example, adidas has created its own KPI (Key Performance Indicator) consisting of six units of measure (adidas, 2008a, p. 36). While the company reports the average score in each of the units of measure, there is no way to interpret these data, either by comparing them with adidas' own past performance or with the performance of another company. Nike has a seemingly similar system of auditing the compliance of its suppliers with company policies but it reports the results of this compliance in very different terms than does adidas (Nike, 2007a, pp. 3032). In short, there is no way to conclude which company is doing a better job of managing its supply chain.

Differences in how performance is measured exist in the reporting of environmental and employee dimensions as well. In communicating information about its workforce, adidas not only has a gender breakdown but also discloses average age, average tenure in position, turnover rates, and number of hours of training per employee (adidas, 2008b, p. 70). Nike, on the other hand, discloses the breakdown based upon gender and ethnicity but does not disclose any of the other information that adidas does about its employees (Nike, 2007b, p. 100). So who is the better employer? Who would you rather work for? No meaningful comparisons between the two companies can be made due to the lack of common information being presented.

Of the nine economic performance indicators in the G3 Guidelines, Nike reports on five - 3 completely; 2 only partially. In addition, Nike provides some information on 12 of the 30 environmental indicators (9 complete; 3 partial), partial information on 5 of the 14 indicators for labor and decent work (complete information on none), on 
eight of the nine human rights indicators, on 3 of the 8 indicators for society, and gives partial information on only one of the 9 core indicators for product responsibility.

Adidas' reporting is even patchier. Of the nine economic indicators in the G3 Guidelines, adidas reports on only one. The company provides information on only 2 of the 30 environmental indicators, on 2 of the 14 indicators for labor and decent work, on 4 of the 9 human rights indicators, on none of the 8 indicators for society, and on 2 of the 9 core indicators for product responsibility. Relative to Nike or indeed to any other organization, adidas' compliance with the G3 Guidelines is minimal at best. One wonders why the company bothers to go through the motions of referencing the G3 Guidelines at all.

After analyzing the content of the Nike and adidas Sustainability Reports, it would seem that the $G 3$ Guidelines are not achieving their intended results of providing an equivalent in TBL reporting to GAAP for financial reporting. Rather than presenting common denominators for comparison of the two companies' economic, environmental, and social performance, the disparity in the amounts and types of core performance indicators presented by Nike and adidas makes any comparison between the two companies impossible.

The student teams perform their own analysis of whether the G3 Guidelines do indeed help measure and communicate the value created by the companies they have selected. Some teams do find the G3 information facilitates comparisons of relative economic, environmental, and social performance. Others do not. At least to this point, the goal of having a GAAP analog to sustainability report seems to still be very much a work in progress. If TBL reporting does indeed represent a more comprehensive way to measure and communicate value creation and the G3 Guidelines are intended to insure that consistent, comparable, hard data are provided, a more generally accepted, perhaps mandatory, system of TBL reporting needs to be developed.

One of the strengths of this class project is its long shelf-life. I expect to be able to use this assignment into the foreseeable future. Because the G3 Guidelines were issued in October 2006, the first and second waves of sustainability reports using these guidelines are just now available. Addition GRI adoptions and refinements are almost a certainty as sustainability reporting continues to evolve. As the communication of a broader range of value creation emerges, I expect that my students will be arriving at very different conclusions concerning the comparability of TBL disclosures.

\section{THE BALANCED SCORECARD OF VALUE CREATION: CAR SHOPPING}

Gas prices, fuel efficiency, and going green have become one of the most hotly debated economic and political issues. My concern with fuel efficient transportation has even longer standing. In 2004, when I logged the $120,000^{\text {th }}$ mile on my car, I was in the market for a new vehicle. With its much publicized EPA estimates of $55 \mathrm{mpg}$ (Highway); $60 \mathrm{mpg}$ (City), the Toyota Prius seemed like a great car for an environmentally conscious consumer like me. Clearly, I was not alone in this opinion. When I went to my local Toyota dealer, I was told there was an 18month wait for the Prius. Eighteen months? How could that be? Didn't Toyota understand that my car is on its last legs and I can't wait 18 months for my Prius?

Value is not created in a functional silo. Business challenges and opportunities are not segregated by functional area. There is no such thing as a marketing problem or an accounting problem or a finance problem or a management problem. There are only business problems which may have elements of each discipline at their roots and in their solutions. Yet the way business education in general and undergraduate business education in particular is delivered, one would think that value is created only by a particular functional specialty. It fails to convey the necessary interrelationships that are part and parcel of the value an organization creates for its stakeholders.

Developed by Bob Kaplan and Tom Norton (1996), the BSC explicitly addresses four value drivers of organizational performance - financial, customer, internal, and learning \& growth. Another way of expressing the BSC is it views an organization through four different but interrelated lenses - in terms of past performance, future potential, an outsider's view, and an insider's perspective. Traditionally, accounting courses have focused primarily, if not exclusively, on financial measures such as profitability, cash flow, sales growth and return on equity to assess a company's performance. However, such a focus fails to capture the necessary interrelationships among the 
perspectives. In addition, the use of financial measures alone does not and cannot capture the value created by intangible assets (measures in the growth \& learning perspective) which often create the competitive advantage for a company (Kaplan \& Norton, 2001; Lev, 2001). Furthermore, disappointing financial results often stem from serious problems in core business processes (i.e., measures in the internal perspective). Most critically, as one author notes, using financial measures alone is like driving a car looking through the rear view mirror (Niven, 2005).

The BSC explicitly addresses four value drivers of organizational performance - financial, customer, internal, and learning \& growth. The customer perspective "defines the value proposition the organization intends to use to generate sales and loyalty from targeted customers" (Kaplan \& Norton, 2004a, p. 54). In other words, the value proposition is what differentiates a company from its competitors. Typical customer-related measures are customer satisfaction and customer loyalty. However, in order to create customer satisfaction, the company must develop sound organizational procedures, efficient production systems and on-time delivery schedules. These are types of internal business processes which need to be understood by employees in order to provide the types of goods and services that engender customer satisfaction. Finally, an infrastructure of information systems and employee work groups support production and service. Kaplan and Norton (2004a) group these aspects of human capital (skills, training, knowledge), information capital (systems, databases, networks), and organization capital (culture, leadership, alignment, teamwork) into the "future" component of the BSC. Consequently, research and development activities as well as employee productivity, employee satisfaction and employee retention are some indicators of the learning and growth component.

These four perspectives are not all-inclusive. Differing strategies of organizations dictate what should be included in the scorecard. This is the beauty of the BSC. It can be adapted and expanded to include metrics on leadership (Van De Vliet, 1997), supplier relationships (Partridge \& Perren, 1997), workforce diversity (Knouse \& Stewart, 2003), the strategic readiness of intangible assets (Kaplan \& Norton, 2004a), community investment (Kaplan \& Norton, 2004b), and/or corporate social responsibility (Crawford \& Scaletta, 2005). Indeed, Kaplan \& Norton (1996) suggest any stakeholder interest which defines a business unit's mission should be included in the BSC. In other words, all relevant TBL measures can and should be incorporated into an organization's BSC.

It is important to recognize the hierarchical nature of the BSC. The basic model assumes that financial performance is the ultimate goal of a business (Bryant, Jones \& Widener, 2004). Lead indicators in the Growth \& Learning, Internal, and Customer Perspectives drive future financial performance. In effect, financial measures merely report the outcomes from past actions in the lower levels in the hierarchy. The key to the successful implementation of the BSC is to find the cause-and-effect linkages that create value (Kaplan \& Norton, 2001). For example, investment in employee training (Learning \& Growth Perspective) will have an impact on innovation, customer management, quality enhancement and other business processes (Internal Perspective), which, in turn, will create greater customer satisfaction (Customer Perspective), resulting in superior financial outcomes (Financial Perspective).

In order to address the cross-functional, interdisciplinary nature of value creation, I introduce my students to a balanced scorecard (BSC) approach in the context of my car buying dilemma. I need a car. I want a fuel efficient one. What does Toyota have to do in order to create value for me and for itself? It has to provide me with the car I want in a timely manner. If it doesn't, it will lose the sale. This is where the four perspectives of the BSC come into play.

Recognizing the hierarchical nature of the BSC, Toyota should invest in its employees' training and its production systems so that it can improve its internal processes. In particular, Toyota needs to assure that its internal processes can shorten the time it takes to manufacture its Prius, without sacrificing on the quality of the car. If it is able to make these improvements, then delivery should be reduced from 18 months to a more acceptable waiting period. A short delivery time will engender higher customer satisfaction, leading to greater customer loyalty. The pay-off? Greater customer loyalty results in higher revenues, profits, return on assets and equity.

The application of this strategy map to my car buying dilemma is an almost perfect fit. Indeed, given the popularity of the BSC in actual practice, the most recent editions of many managerial accounting textbooks contain their own examples of the value created by a company through the four inter-related lenses of the BSC. (See for 
example, Atkinson et al. , 2007, pp. 392-432; Bamber et al. 2008, pp. 671-676; Garrison et al, 2008, pp. 438-448; Hilton, 2008, pp. 427-432.)

I ask my students to create their own strategy map for the companies they are studying. My hope is that they will make connections between the shadow accounting and TBL/GRI projects they have completed and this BSC assignment. At the very least, I want them to work through the interrelationships among and between the BSC perspectives. I have found it most interesting that of the four perspectives, my students have struggled most with finding metrics for value creation in the Learning \& Growth Perspective because this is where many corporate initiatives for value creation should and do begin.

\section{CONCLUSION}

Value creation is different from revenue or profit generation. It is richer, broader, more challenging, and more conflicting than maximization of shareholder wealth. As I begin every semester with my question (what would you like to know about a company?), I could easily begin the course with another - what value do you want your company or organization to create? The answers would be the same.

Where does accounting come in to this? The role of accounting is to measure and communicate. If accounting does not measure and communicate all the various types of value an organization creates, it has failed. The exercises, examples, projects and approaches offered in the paper are intended to help students gain an appreciation of the role accounting can and should play and a better understanding of how accounting succeeds or fails in this regard.

\section{AUTHOR INFORMATION}

W. Richard Sherman is a Professor of Accounting at the Saint Joseph's University's Haub School of Business in Philadelphia, Pennsylvania. After majoring in Sociology as an undergraduate, Rick earned his law degree, an MBA with a concentration in Accounting, and a graduate degree in tax law. Recipient of numerous awards for teaching excellence, including the prestigious Lindback Foundation Award for Distinguished Teaching, Professor Sherman has published over 50 articles in academic and professional journals. His research spans issues in accounting education, tax, uses of accounting information, and sustainability/Triple Bottom Line reporting.

\section{REFERENCES}

1. Adidas Group (2008a). Giving 110\%: our effort to be a responsible business in 2007. Available at http://www.adidas-group.com/en/SER2007/pdf/adidas_SER2007_report.pdf (accessed 10 September 2008).

2. Adidas Group. (2008b). Striving to improve performance: 2007 corporate responsibilityreport. (Web version). Available at http://www.adidas-group.com/en/SER2007/ (accessed 10 September 2008).

3. Adidas Group. (2008c). GRI index. Available at http://www.adidas-group.com/en/SER2007/gri_index.asp. (accessed 10 September 2008).

4. adidas Group. (2008d). Statement on verification. Available at http://www.adidasgroup.com/en/sustainability/reporting/statement on_verification/default.asp (accessed 10 September 2008).

5. Atkinson, A., R. Kaplan, E. Matsumura \& S. Young (2007). Management accounting, $5^{\text {th }}$ Edition. Upper Saddle River, NJ: Pearson Education.

6. Bamber, L., K. Braun \& W. Harrsion (2008). Managerial accounting. Upper Saddle River, NJ: Pearson Education.

7. Bryant, L., D.A. Jones \& S.K. Widener (2004). Managing value creation within the firm: An examination of multiple performance measures. Journal of Management Accounting Research. 16:106-131.

8. Corporate Register (2008). CR reporting awards '07: global winners and reporting trends. Available at http://www.corporateregister.com/pdf/CRRA07.pdf (accessed 10 September 2008).

9. Crawford, D. \& T. Scaletta (2005). The balanced scorecard and corporate social responsibility: aligning values for profit. CMA Management (October 2005): 20-27. 
10. Elkington, J. (1997). Cannibals with forks: the triple bottom line of the $21^{\text {st }}$ century business. Oxford: Capstone.

11. Epinions (2008). The miracle blade. Available at http://www.epinions.com/review/Miracle_Blade_Perfection_Series_Knives/content_155639582340 (accessed 10 September 2008).

12. Ethisphere (2007). World's most ethical companies. Available at http://ethisphere.com/2007-worlds-mostethical-companies/ (accessed 10 September 2008).

13. Garrison, R, E. Noreen \& P. Brewer (2008). Managerial accounting, $12^{\text {th }}$ Edition. Boston: McGrawHill/Irwin.

14. Global Reporting Initiative (GRI, 2000). Sustainability reporting guidelines on economic, environmental, and social performance. Boston: Coalition for Environmentally Responsible Economies.

15. Global Reporting Initiative (GRI, 2002). Sustainability reporting guidelines. Available at http://www.aeca.es/comisiones/rsc/documentos_fundamentales_rsc/gri/guidelines/gri_guidelines_2002.pdf (accessed 10 September 2008).

16. Global Reporting Initiative (GRI, 2006). Sustainability reporting G3 guidelines. http://www.globalreporting.org/NR/rdonlyres/ED9E9B36-AB54-4DE1-BFF2-

5F735235CA44/0/G3_GuidelinesENU.pdf (in hardcopy); also available in on-line version at http://www.globalreporting.org/ReportingFramework/G3Online/ (accessed 10 September 2008).

17. Gray, R. (1992). Accounting and environmentalism: an exploration of the challenge of gently accounting for accountability, transparency, and sustainability. Accounting, Organizations and Society 17(5): 399-425.

18. Gray, R., Bebbington J., \& Walters, D. (1993). Accounting for the environment. Princeton: Markus Wiener Publishers.

19. Hilton, R. (2008). Management Accounting: Creating Value in a Dynamic Business Environment, $7^{\text {th }}$ Edition. Boston: McGraw-Hill/Irwin.

20. Infomercial Ratings (2006). The miracle blade. Available at http://www.infomercialratings.com/product/miracle_blade (accessed 10 September 2008).

21. JustAccountancyJobs.com (2008). Accountants to balance carbon books. 09 April 2008. Available at http://www.earthtimes.org/articles/show/accountants-to-balance-carbon-books,345230.shtml (accessed 10 September 2008).

22. Kaplan, R.S. \& D.P. Norton (1992). The balanced scorecard: measures that drive performance. Harvard Business Review (Jan-Feb 1992): 71-79.

23. Kaplan, R.S. \& D.P. Norton (1996). The balanced scorecard: translating strategy into action. Boston, MA.: Harvard Business School Press.

24. Kaplan, R.S. \& D.P. Norton (2001). The strategy-focused organization: How balanced scorecard companies thrive in the new business environment. Boston, MA: Harvard Business School Press.

25. Kaplan, R.S. \& D.P. Norton (2004a). Measuring the strategic readiness of intangible assets. Harvard Business Review (Feb 2004): 52-63.

26. Kaplan, R.S. \& D.P. Norton (2004b). Keeping score on community investment. Leader to Leader (Summer 2004) 33: 13-19.

27. Knouse, S. B. \& J.B. Stewart (2003). "Hard" measures that support the business case for diversity: A balanced scorecard approach. Overcoming Barriers to Opportunity 11(4): 5-10.

28. Kolk, A. (2008). Sustainability, accountability and corporate governance: exploring multinationals' reporting practices. Business Strategy and the Environment 17(1): 1-15.

29. Lev, B. (2001). Intangibles: Management, Measurement, and Reporting. Washington DC: Brookings Institution Press.

30. Locke, R. M. (2003). The promise and perils of globalization: the case of Nike. In Thomas A. Kochan and Richard Schmalensee (eds): Management: Inventing and delivering its future. Cambridge, MA, MIT Press, pp. 39-70.

31. Major League Baseball (MLB; 2008). Red goes green. Available at http://mlb.mlb.com/news/press_releases/press_release.jsp?ymd=20080430\&content_id=2614303\&vkey=pr _phi\&fext=.jsp\&c_id=phi (accessed 10 September 2008).

32. Miracle Blade (2008). Available at http://www.miracleblade.com/ (accessed 10 September 2008). 
33. Nike (2007a). Innovate for a better world: Nike FY 05/06 corporate responsibility report. Available at http://www.nikeresponsibility.com/pdfs/color/Nike_FY05_06_CR_Report_C.pdf (accessed 10 September 2008).

34. Nike (2007b). Innovate for a better world. (Web version). Available at http://www.nikeresponsibility.com/\#home/ (accessed 10 September 2008).

35. Nike (2007c). Guidelines and principles index. Innovate for a better world: Nike FY 05/06 corporate responsibility report. Available at http://www.nikeresponsibility.com/pdfs/color/13_Nike_CRR_GRI_Index_C.pdf (accessed 10 September 2008).

36. Niven, P.R. (2005). Driving focus and alignment with the balanced scorecard. The Journal for Quality \& Participation (Winter 2005): 21-43.

37. Partridge, M. \& L. Perren (1997). Winning ways with a balanced scorecard. Accountancy 120: 50-51.

38. Terrapass (2008). Restore the balance. Available at www.terrapass.com (accessed 10 September 2008).

39. Van de Vliet, A. (1997). A new balancing act. Management Today: 78-80. 